\title{
PENGARUH KECEPATAN ALIRAN FLUIDA TERHADAP DISTRIBUSI TEMPERATUR PERMUKAAN BAHAN BAKAR TERAS REAKTOR
}

\author{
Adolf Asih Supriyanto \\ Lab Fisika, Program Studi Teknik Mekatronika \\ Politeknik Enjinering Indorama, Purwakarta \\ Email: adolf@pei.ac.id
}

\begin{abstract}
ABSTRAK
Pada penelitian ini telah dipelajari aspek termohidrolika teras reaktor mengenai temperatur permukaan bahan bakar dan fluida akibat pengaruh kecepatan aliran fluida. Telah dilakukan pemodelan susunan teras reaktor dan reflektor berbentuk heksagonal. Berikutnya, diasumsikan bahwa pembangkitan dayanya tetap pada $6,89 \times 10^{4} \mathrm{kwatt} / \mathrm{m}^{2}$ untuk masing-masing bahan bakar. Kecepatan aliran fluida diatur sebesar 1,8 dan $2 \mathrm{~m} / \mathrm{s}$. Data pengamatan diperoleh dari distribusi temperatur pada permukaan bahan bakar dan fluida, khususnya pada sub-buluh tengah, pinggir dan pojok. Pengerjaan model teras reaktor dilakukan dengan paket program Fluent Versi 4.25. Hasil yang diperoleh menunjukkan bahwa teras reaktor yang dimodelkan memiliki temperatur bahan bakar dan fluida cukup rendah.
\end{abstract}

Kata kunci: bahan bakar, teras reaktor, pembangkitan daya, fluent, sub-buluh.

\section{ABSTRACT}

In this experiment, it was studied reactor core thermohydraulic aspect especially fuel surface and fluid temperatures due to the influence of the fluid flow velocity. Modelling of hexagonal configuration of reactor core and reflection was carried out. Then, the power generation was assumed constant at $6.89 \times 10^{4} \mathrm{kwatt} / \mathrm{m}^{2}$ for each fuel elements. Fluid flow velocity were set at 1.8 and $2.0 \mathrm{~m} / \mathrm{s}$. Simulation data were obtained from the fuel surface and fluid distribution temperatures, especially in the middle, edge and corner sub-channels. This model was prepared and analyzed using Fluent Version 4.25 package program. The results show that this reactor core model gives low surface and fluid temperatures.

Keywords: fuel, reactor core, power generation, fluent, channel.

\section{PENDAHULUAN}

Beberapa reaktor yang dimiliki pemerintah Indonesia berdasarkan fungsinya termasuk jenis reaktor penelitian, dimana neutron hasil belah dimanfaatkan untuk berbagai keperluan seperti penelitian, irradiasi dan produksi radioisotop [1-2]. Prioritas utama dari pendayagunaan reaktor dimasa mendatang diantaranya adalah produksi radioisotop terutama Fission Product Molybdenum (FPM) [3-4].

Bahaya yang selalu ditimbulkan oleh penggunaan reaktor nuklir adalah bahaya terakumulasinya zatzat radioaktif sebagai hasil reaksi belah yang terjadi pada teras reaktor nuklir [5-6]. Mengingat bahaya tersebut, maka dituntut pengoperasian reaktor pada tingkat daya yang tepat dengan sistem pendingin yang mampu mengeluarkan panas dari teras reaktor secara maksimal. Penerapan persyaratan keselamatan yang sangat ketat perlu dilakukan untuk pembangunan reaktor nuklir dan pengoperasiannya. Berkaitan dengan faktor keselamatan, peranan aspek termohidrolika menjadi sangat penting karena aspek termohidrolika dapat membatasi operasi reaktor. Dalam melakukan perancangan dan penganalisisan termohidrolika dituntut suatu ketelitian yang sangat tinggi. Oleh itu, kajian aspek termohidrolika perlu dilakukan.

Masih terbatasnya informasi tentang aspek termodihrolika dari kajian eksperimen maka kajian teoritik sangat diperlukan untuk menunjuang kajian eksperimen tersebut. Kajian teoritik dapat mengetahui tentang data distribusi temperatur sepanjang bahan bakar serta temperatur dan kecepatan aliran fluida pendingin pada setiap tempat, sehingga data tersebut dapat memprediksi tingkat paparan radiasi pada permukaan fluida dalam tangki reaktor. Data ini secara eksperimen sangat sulit dilakukan.

Dalam penelitian ini akan dilakukan modifikasi terhadap susunan bahan bakar di teras reaktor Triga Mark II di Bandung dari susunan bentuk semula lingkaran menjadi bentuk susunan heksagonal dengan jumlah bahan bakar sebanyak 121 batang seperti yang ditunjukkan dalam Gambar 1. Diharapkan dari penelitian ini diperoleh data-data tambahan dalam usaha untuk meningkatkan pengoperasian reaktor Triga Mark II menjadi 2 MW. 


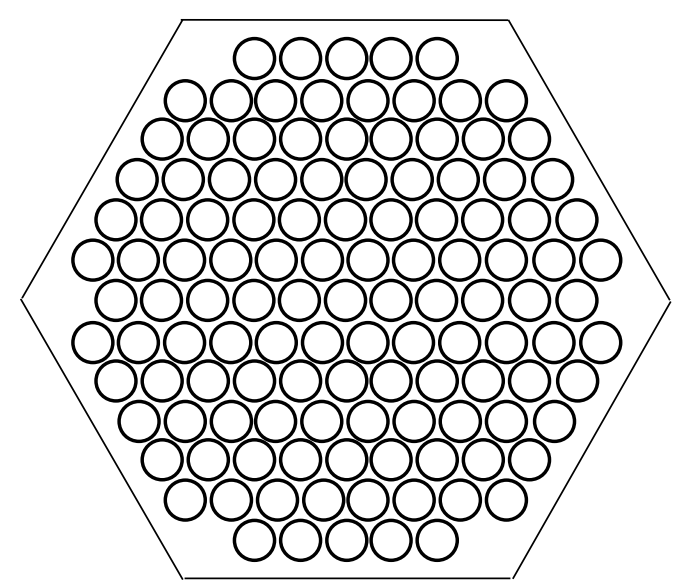

Gambar 1. Penampang Susunan Heksagonal Bahan Bakar Di Dalam Teras Reaktor Yang Dikaji

Kajian dalam penelitian ini dibatasi pada aspek termohidrolikanya saja. Karena adanya faktor simetri daripada susunan bahan bakar teras reaktor yang dikaji maka pembuatan model teras rekator hanya mencakupi seperduabelas $(1 / 12)$ dari susunan bahan bahar teras reaktor saja. Diasumsikan pembangkitan dayanya tetap sebesar $6,89 \times 10^{4} \mathrm{watt} / \mathrm{m}^{2}$. Sedangkan aliran fluida yang masuk kedalam teras reaktor diatur 1,8 dan $2 \mathrm{~m} / \mathrm{s}$ pada temperatur $305^{\circ} \mathrm{K}$ dan tekanan 1 atm. Kajian berikutnya akan dilakukan untuk menentukan distribusi temperatur permukaan bahan bakar dan fluida pendingin. Distribusi temperatur bahan bakar dan fluida difokuskan pada daerah sub-buluh tengah, pinggir dan pojok. Distribusi temperatur baik bahan bakar maupun fluida diperoleh dengan cara mereratakan nilai temperatur pada masing-masing sub-buluk tengah, pinggir dan pojok.

Dalam melakukan kajian aspek termohidrolika dari teras reaktor susunan heksagonal dalam penelitian ini, digunakan paket program Fluent Versi 4.25 yang dimiliki oleh Laboratorium Termodinamika, PAU-IR, Institut Teknologi Bandung, Bandung.

\section{TEORI}

Fluent versi 4.25 adalah suatu program paket komputer yang dapat digunakan untuk memodelkan aliran fluida, transfer panas dan reaksi kimia. Dalam penelitian ini, program paket komputer Fluent versi 4.25 digunakan untuk memodelkan aliran fluida dalam teras reaktor susunan heksagonal pada masingmasing sub-buluk tengah, pinggir dan pojok.

\subsection{Persamaan Dasar}

Program paket komputer Fluent Versi 4.25 dalam menyelesaikan aspek termohidrolika dalam teras reaktor menggunakan persamaan-persamaan dasar: konservasi massa, konservasi momentum, konservasi energi dan model aliran turbulensi [8-10].

Persamaan konservasi massa:

$\frac{\partial \rho}{\partial t}+\frac{\partial\left(\rho v_{i}\right)}{\partial x_{i}}=S_{m}$

dengan $\rho=$ densitas fluida

$x_{i}=$ jarak dalam arah $i$

$v_{i}=$ komponen kecepatan dalam arah $i$

$S_{m}=$ sumber lain

Persamaan konservasi momentum:

$$
\begin{aligned}
\frac{\partial\left(\rho v_{i}\right)}{\partial t}+ & \frac{\partial\left(\rho v_{i} v_{j}\right)}{\partial x_{i}}=-\frac{\partial p}{\partial x_{i}}+\frac{\partial \tau_{i j}}{\partial x_{i}}+\rho g_{i}+F_{i} \\
\text { dengan } p & =\text { tekanan statik } \\
g_{i} & =\text { percepatan grafitasi } \\
F_{i} & =\text { gaya luar } \\
\tau_{i j} & =\text { tensor stress }
\end{aligned}
$$


Persamaan konservasi energi:

$$
\begin{aligned}
\frac{\partial(\rho h)}{\partial t}+ & \frac{\partial\left(\rho v_{i} h\right)}{\partial x_{i}}=\frac{\partial}{\partial x_{i}}\left(k \frac{\partial T}{\partial x_{i}}\right)-\frac{\partial}{\partial x_{i}} \sum_{j^{\prime}} h_{j^{\prime}} J_{j^{\prime}}+\frac{\partial p}{\partial t}+v_{i} \frac{\partial p}{\partial x_{i}}+\tau_{i j} \frac{\partial v_{i}}{\partial x_{j}}+s_{h} \\
\text { dengan } & T=\text { temperatur } \\
J_{j^{\prime}} & =\text { fluks spesies } j^{\prime} \\
k & =\text { konduktivitas termal campuran } \\
h & =\text { entalpi } \\
S & =\text { sumber }
\end{aligned}
$$
Reynolds.

$$
\begin{aligned}
\rho\left(\overline{u_{i}^{\prime} u_{j}^{\prime}}\right) & =\mu_{t}\left(\frac{\partial \overline{u_{i}}}{\partial x_{j}}+\frac{\partial \overline{u_{j}}}{\partial x_{i}}\right)-\frac{2}{3} \rho k \delta_{i j} \\
\text { dengan } \quad \bar{u} & =\text { komponen kecepatan rata-rata } \\
k & =\text { energi kinetik turbulen } \\
\mu_{t} & =\text { viskositas turbulen } \\
\delta_{i j} & =\text { delta kroneker. } i=1,2,3 ; j=1,2,3
\end{aligned}
$$

\subsection{Kondisi Batas}

Program paket Fluent Versi 4.25 menggunakan kondisi batas masukkan, simetri dan dinding.

\subsubsection{Masukkan}

Batasan masukkan adalah batasan aliran fluida yang masuk kedalam teras reaktor dengan kecepatan, temperatur dan besaran fisis yang diketahui. Besaran-besaran fisis fluida, dalam penelitian ini adalah air, dengan tetapan-tetapan sebagi beikut:

a) Densitas, $\rho=9,583 \times 10^{2} \mathrm{~kg} / \mathrm{m}^{3}$

b) Viskositas, $\mu=2,822 \times 10^{-4} \mathrm{~kg} / \mathrm{m}-\mathrm{s}$

c) Konduktivitas panas, $k=6,77 \times 10^{-1} \mathrm{watt} / \mathrm{m}-\mathrm{K}$

d) Panas jenis, $c_{p}=4,216 \times 10^{3}$ Joule $/ \mathrm{kg}-\mathrm{K}$

\subsubsection{Simetri}

Batasan simetri adalah batasan bidang simetri dimana gradien normal sama dengan nol untuk semua variabel kecuali komponen normal kecepatan. Kecepatan normal akan hilang pada batasan simetri.

\subsubsection{Dinding}

Pada batasan dinding komponen kecepatan normal dipaksa sama dengan nol, dan harga fluks skalar dipilih tetap. Pada batasan dinding pembangkitan panas dinyatakan oleh:

$$
q_{w}^{\prime \prime}=k \frac{\Delta T}{\Delta n}=h_{\infty}\left(T_{\infty}-T_{w}\right)
$$

dengan $q_{w}^{\prime \prime}=$ pembangkitan panas

$k=$ konduktivitas termal fluida

$T=$ temperatur

$w=$ dinding

$\Delta n=$ jarak dari dinding ke titik nodal dekat dinding

$\infty=$ cukup jauh dari dinding

Pembangkitan panas dari dinding untuk aliran turbulen dinyatakan dengan formula log-low sebagai berikut: 


$$
\frac{k\left(\frac{\Delta T}{\Delta n}\right)}{q^{\prime \prime}}=\frac{1}{\kappa y^{+}} \frac{\operatorname{Pr}_{t}}{\operatorname{Pr}} \ln \left(E y^{+}\right)+\frac{1}{y^{+}}\left(\frac{\operatorname{Pr}_{t}}{\operatorname{Pr}}\right)^{\frac{3}{4}} \frac{\left(\frac{\pi}{4}\right)}{\sin \left(\frac{\pi}{4}\right)}\left(\frac{A}{\kappa}\right)^{\frac{1}{2}}\left(\frac{\operatorname{Pr}}{\operatorname{Pr}_{t}}-1\right)
$$

dengan $q_{w}^{\prime \prime}=$ pembangkitan panas

$k=$ konduktivitas termal fluida

$\Delta T=T_{w}-T_{f}$

$W=$ dinding

$F=$ fluida

$\mathrm{Pr}=$ bilangan Prandtl

$\kappa=$ konstanta von-Karman $(0,24)$

$A=$ konstanta van-Driest (26)

$E=$ konstanta empiris $(9,81)$

$y^{+}=$konstanta jarak dari dinding $(11,225)$

Proses penyelesain persamaan-persamaan tersebut di atas yang dilakukan oleh program paket Fluent Versi 4.25 dalam memperoleh solusi persamaan pengendali dapat merujuk kepada Nazar dkk, 1998 [11].

\section{METODOLOGI PENELITIAN}

Pada penelitian ini dibahas tentang disain bahan bakar reaktor, teras reaktor dan data masukkan.

\subsection{Bahan Bakar Reaktor}

Dalam penelitian ini model ukuran bahan bakar reaktor ditunjukkan dalam Gambar 2. Jumlah semua bahan bakar reaktor ada 121 batang, dengan masing-masing bahan bakar reaktor memiliki ukuran diameter dan panjang adalah 37,6 dan $381 \mathrm{~mm}$. Selongsong bahan bakar reaktor terbuat dari stainless steel. Bahan bakar tersebut diapit pada sisi bawah dan atas oleh grafit dengan diameter yang sama, namun panjang yang berbeda yaitu $88 \mathrm{~mm}$. Sedangkan susunan bahan bakar reaktor ditunjukkan dalam Gambar 3 dengan jarak dari pusat ke pusat bahan bakar satu dengan bahan bakar yang lainnya adalah $408 \mathrm{~mm}$.
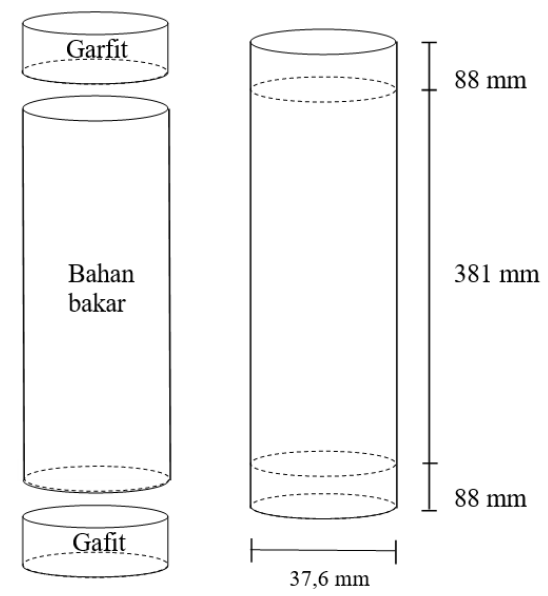

Gambar 2. Model Ukuran Bahan Bakar Dari Teras Reaktor

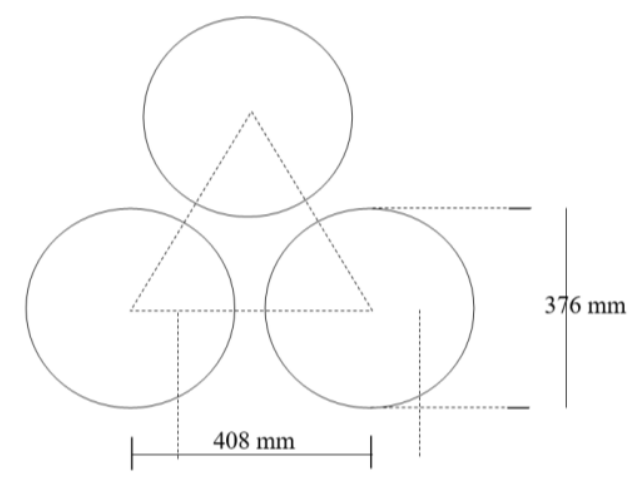

Gambar 3. Susunan Bahan Bakar Reaktor 
Daya yang dibangkitkan oleh setiap bahan bakar reaktor diasumsikan tetap sebesar $6,89 \times 10^{4} \mathrm{watt} / \mathrm{m}^{2}$ dan terdistribusi secara merata sepanjang bagian bahan bakar tersebut. Bagian luar dari bahan bakar adalah tidak aktif dan diasumsikan sebagi dinding adiabatik.

\subsection{Teras Reaktor}

Merujuk kepada pemodelan susunan heksagonal bahan bakar reaktor pada Gambar 1 terlihat ada kesimetrian bidang. Dalam penelitian ini, teras reaktor dibuat seperduabelas dari model susunan heksagonal bahan bakar reaktor seutuhnya seperti yang ditunjukkan dalam Gambar 4. Selanjutnya penelitian hanya dibatasi pada sub-buluh tengah, pinggir dan pojok seperti yang ditunjukkan dalam Gambar 4(a).

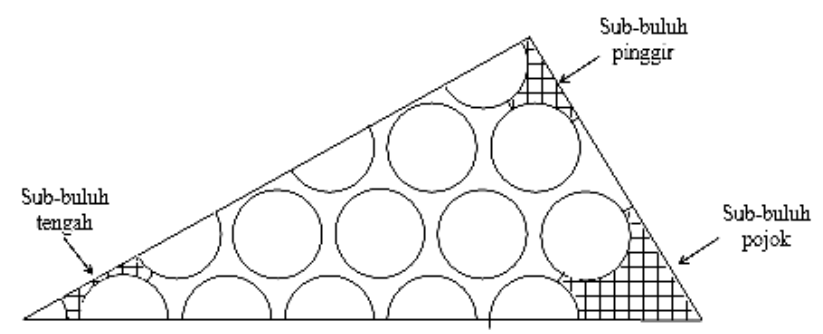

(a)

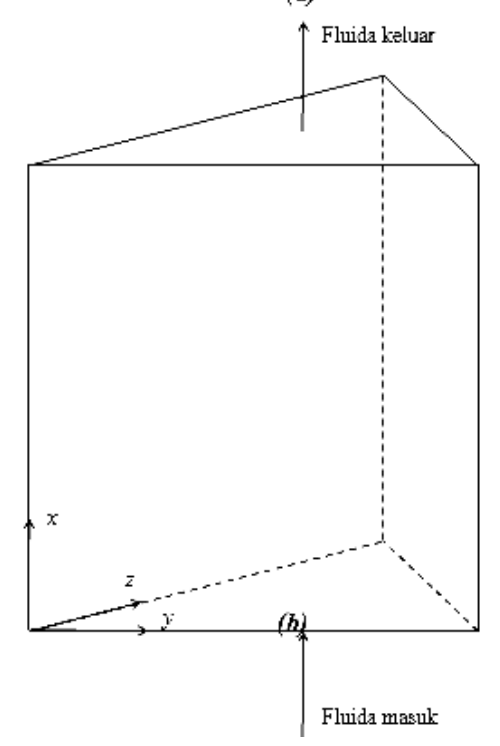

Gambar 4. Geometri 1/12 Teras Reaktor (a) Tampak Dari Atas Dan (b) Visualisasi Geometri Model 3-Dimensi

Gambar 4 (b) adalah visualisasi model teras reaktor dalam 3-dimensi. Fluida pendingin masuk dari bawah bergerak sepanjang sumbu- $x$ arah vertikal dan keluar ke atas didalam teras reaktor. Program paket Fluent Versi 4.25 memerlukan pembagian grid arah sumbu- $x, y$ dan $z$. Pada penelitian ini dibuatlah grid dengan 14 nodal arah sumbu- $x, 18$ nodal arah sumbu- $y$ dan 29 nodal arah sumbu- $z$. Pembagian sel volume atur ditunjukkan dalam Tabel 1 . Seterusnya dalam pembahasan sel volume atur dalam sumbu- $x$ diganti dengan posisi.

Tabel 1. Sel volume atur dalam sumbu-x

\begin{tabular}{cccc}
\hline No. & Jarak dalam sumbu-x $(\mathbf{c m})$ & Jumlah sel volume atur & Posisi \\
\hline 1 & $0 \sim 88$ & 2 & $1 \sim 2$ \\
2 & $88 \sim 469$ & 8 & $3 \sim 10$ \\
3 & $469 \sim 557$ & 2 & $11 \sim 12$ \\
\hline
\end{tabular}

\subsection{Data Masukan}

Dalam penelitian ini beberapa data masukan dibuat tetap seperti temperatur dan tekanan aliran fluida masuk masing-masing dengan nilai $305^{\circ} \mathrm{K}$ dan 1 atm. Sedangkan kecepatan fluida divariasikan dengan nilai 1,8 dan $2,0 \mathrm{~m} / \mathrm{s}$. Pembangiktan panas untuk grafit diatur sama dengan $0 \mathrm{watt} / \mathrm{m}^{2}$, sedangkan pembangkitan daya untuk bahan bakar, dihitung menurut perhitungan sebagai berikut: 


$$
\begin{aligned}
& W=\frac{P}{\left(\sum B b\right) \cdot(A)} \text { watt } / \mathrm{m}^{2} \\
& \text { dengan: } \\
& W=\text { pembangkitan daya } \\
& P=\text { daya } \\
& B b=\text { bahan bakar } \\
& A=\text { luas selubung bahan bakar }
\end{aligned}
$$

Pembangkitan daya pada bahan bakar diatur untuk harga daya $P$ yaitu 375 kwatt. Jika harga daya $P$ tersebut dimasukkan kedalam persamaan 7, maka diperoleh harga pembangkitan daya $W$ sebesar $6,89 \times 10^{4} \mathrm{watt} / \mathrm{m}^{2}$.

\section{HASIL DAN PEMBAHASAN}

Pada penelitian ini reaktor dianggap beroperasi pada pembangkitan daya sebesar $6,89 \times 10^{4} \mathrm{watt} / \mathrm{m}^{2}$.

\subsection{Distribusi Temperatur Bahan Bakar}

Distribusi temperatur permukaan bahan bakar sepanjang posisi dalam arah sumbu- $x$ dengan pembangkitan daya $6,89 \times 10^{4}$ watt $/ \mathrm{m}^{2}$ dan kecepatan fluida $1,8 \mathrm{~m} / \mathrm{s}$ ditunjukkan dalam Gambar 5 . Pada awal masuknya fluida kedalam teras reaktor temperatur permukaan bahan bakar adalah konstan $305^{\circ} \mathrm{K}$ seperti yang ditunjukkan dalam posisi 1 dan 2 dalam Gambar 5 karena fluida melewati grafit dengan pembangkitan daya $0 \mathrm{watt} / \mathrm{m}^{2}$. Kemudian pada posisi 3 temperatur permukaan bahan bakar mulai naik menjadi $346,5^{\circ} \mathrm{K}$ pada sub-buluh pojok dan $356,1^{\circ} \mathrm{K}$ pada sub-buluh pinggir dan tengah. Temperatur permukaan bahan bakar terus meningkat dengan meningkatnya posisi sampai dengan posisi 10 menjadi $350,1^{\circ} \mathrm{K}$ pada sub-buluh pojok, $364,7^{\circ} \mathrm{K}$ pada sub-buluh pinggir dan $366,2^{\circ} \mathrm{K}$ pada sub-buluh tengah. Meningkatnya temperatur permukaan bakar tersebut terhadap meningkatnya posisi disebabkan fluida yang melewati bahan bakar mendapat tambahan panas secara terus-menerus sehingga fluida tidak dapat menyerap panas lebih banyak dari permukaan bahan bakar. Temperatur pemukaan bahan bakar pada subbuluh pojok lebih rendah daripada sub-buluh pinggir dan tengah. Hal ini karena volume fluida yang melewati sub-buluh pojok lebih besar sehingga fluida dapat menyerap panas lebih banyak yang menyebabkan temperatur bahan bakar semakin berkurang. Terakhir temperatur permukaan bahan bakar turun kembali karena fluida melewati grafit yang pembangkitan dayanya sama dengan $0 \mathrm{watt} / \mathrm{m}^{2}$.

Gambar 6 adalah distribusi temperatur permukaan bahan bakar sepanjang posisi dalam arah sumbu- $x$ dengan pembangkitan daya $6,89 \times 10^{4}$ watt $/ \mathrm{m}^{2}$ dan kecepatan fluida $2,0 \mathrm{~m} / \mathrm{s}$. Distribusi temperatur permukaan bahan bakar pada Gambar 6 memiliki kecenderungan yang sama dengan distribusi temperatur permukaan bahan bakar pada Gambar 5. Temperatur permukaan bahan bakar terus meningkat dengan meningkatnya posisi yaitu dari posisi 3 sehingga 10. Pada posisi 3 temperatur permukaan bahan bakar menjadi $343,8^{\circ} \mathrm{K}$ pada sub-buluh pojok dan $353,2^{\circ} \mathrm{K}$ pada sub-buluh pinggir dan tengah. Temperatur permukaan bahan bakar terus meningkat dengan meningkatnya posisi sampai dengan posisi 10 menjadi $347,3^{\circ} \mathrm{K}$ pada sub-buluh pojok dan $361,7^{\circ} \mathrm{K}$ pada sub-buluh tengah. Namun temperatur permukaan bahan bakar pada masing-masing sub-buluh pada Gambar 6 lebih rendah daripada Gambar 5. Hal ini karena semakin besar kecepatan fluida maka semakin cepat pengambilan panas oleh fluida sehingga semakin kecil nilai temperatur permukaan bahan bakar. Temperatur permukaan bahan bakar tertinggi yang diperoleh dalam penelitian ini adalah $366,2^{\circ} \mathrm{K}$ pada sub-buluh tengah.

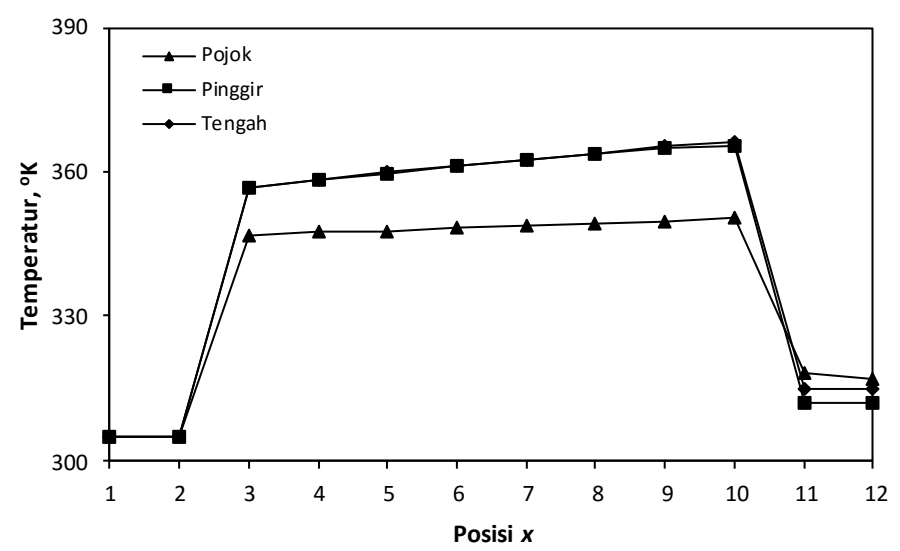

Gambar 5. Distribusi Temperatur Permukaan Bahan Bakar Dengan Kecepatan Awal Fluida 1,8 m/s 


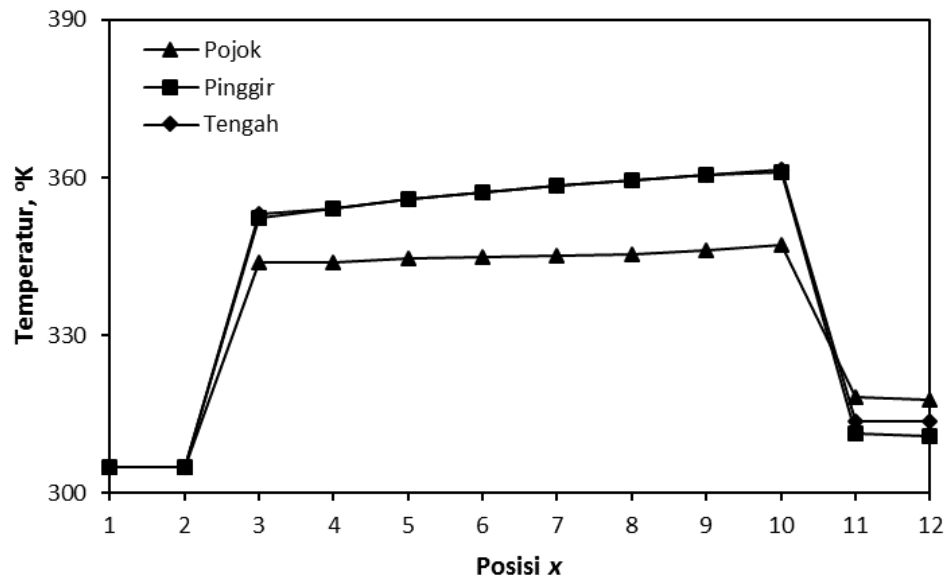

Gambar 6. Distribusi Temperatur Permukaan Bahan Bakar Dengan Kecepatan Awal Fluida 2,0 m/s

Antariksawan dkk pada 2000 telah melakukan perhitungan terhadap temperatur bahan bakar teras reaktor dan mereka memperoleh hasil $134,7^{\circ}$ C [4]. Kemudian, Sudjatmi pada tahun 2011 melakukan kajian mengenai temperatur permukaan kelongsong bahan bakar dan didapati $138^{\circ} \mathrm{C}$ [7]. Sedangkan dalam kajian ini diperoleh temperatur bahan bakar tertinggi adalah $366,2^{\circ} \mathrm{K}$ pada sub buluh tengah, sehingga boleh dikatakan temperatur permukaan bahan bakar tersebut masih dalam katagori aman untuk mengoperasikan reaktor dengan pembangkitan daya $6,89 \times 10^{4} \mathrm{watt} / \mathrm{m}^{2}$.

\subsection{Distribusi Temperatur Fluida}

Distribusi temperatur fluida sepanjang posisi dalam arah sumbu- $x$ dengan pembangkitan daya $6,89 \times 10^{4}$ watt $/ \mathrm{m}^{2}$ dan kecepatan fluida $1,8 \mathrm{~m} / \mathrm{s}$ ditunjukkan dalam Gambar 7 . Pada awal masuknya fluida kedalam teras reaktor temperatur fluida adalah konstan $305^{\circ} \mathrm{K}$ seperti yang ditunjukkan dalam posisi 1 dan 2 dalam Gambar 7 karena fluida melewati grafit dengan pembangkitan daya 0 watt $/ \mathrm{m}^{2}$. Kemudian pada posisi 3 temperatur fluida mulai naik masing-masing pada sub-buluh tengah, pinggir dan pojok menjadi $306,0^{\circ} \mathrm{K}, 306,0^{\circ} \mathrm{K}$ dan $305,3^{\circ} \mathrm{K}$. Temperatur fluida terus meningkat dengan meningkatnya posisi sampai dengan posisi 10 masing-masing pada sub-buluh tengah, pinggir dan pojok menjadi $318,8^{\circ} \mathrm{K}$, $312,3^{\circ} \mathrm{K}$ dan $307,6^{\circ} \mathrm{K}$. Meningkatnya temperatur fluida tersebut terhadap meningkatnya posisi disebabkan terakumulasinaya panas bahan bakar yang diberikan ke fluida. Terakhir temperatur fluida tidak naik lagi karena fluida melewati grafit yang pembangkitan dayanya sama dengan $0 \mathrm{wat} / \mathrm{m}^{2}$, seperti yang ditunjukkan dalam posisi 11 dan 12 pada Gambar 7.

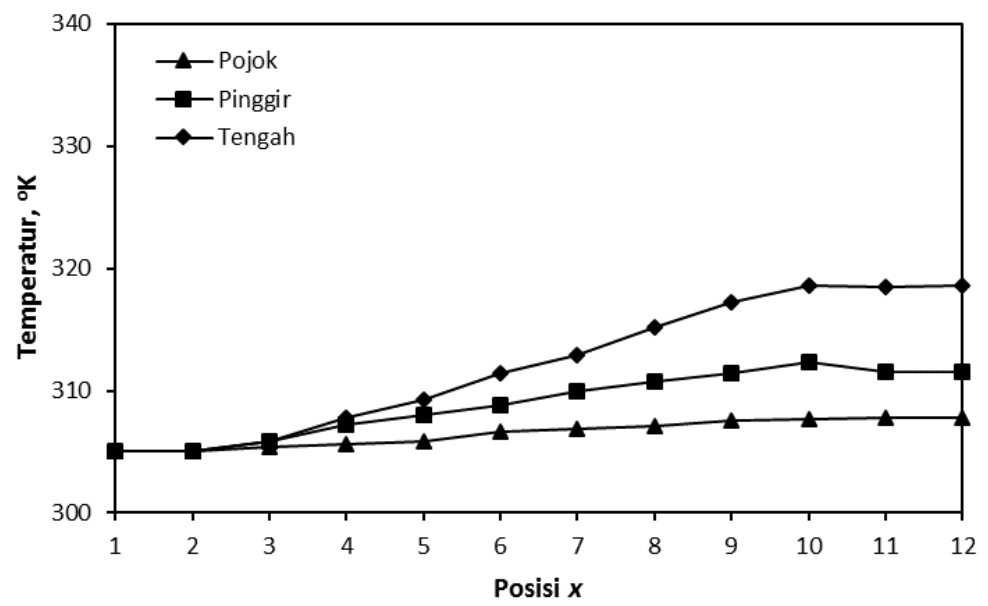

Gambar 7. Distribusi Temperatur Fluida Dengan Kecepatan Awal Fluida 1,8 m/s

Gambar 8 adalah distribusi temperatur fluida dengan pembangkitan daya $6,89 \times 10^{4} \mathrm{watt} / \mathrm{m}^{2}$ dan kecepatan fluida 2,0 m/s. Distribusi temperatur fluida pada Gambar 8 memiliki kecenderungan yang sama dengan distribusi temperatur fluida pada Gambar 7. Temperatur fluida terus meningkat dengan meningkatnya posisi yaitu dari posisi 3 sehingga 10. Namun temperatur fluida pada masing-masing subbuluh pada Gambar 7 lebih rendah daripada Gambar 6. Hal ini karena semakin meningkat kecepatan 
fluida semakin menurun temperatur fluida. Temperatur fluida tertinggi adalah $318.8^{\circ} \mathrm{K}$ pada sub-buluh tengah dengan kecepatan awal fluida $1,8 \mathrm{~m} / \mathrm{s}$.

\section{KESIMPULAN}

Hasil kajian yang telah dilakukan terhadap model teras reaktor dengan memasukkan pembangkitan panas, temperatur dan tekanan fluida konstan masing-masing $6,89 \times 10^{4} \mathrm{watt} / \mathrm{m}^{2}, 305^{\circ} \mathrm{K}$ dan $1,5 \mathrm{~atm}$ serta variasi kecepatan $1,8 \mathrm{~m} / \mathrm{s}$ dan $2,0 \mathrm{~m} / \mathrm{s}$ diperoleh kesimpulan bahwa temperatur permukaan bahan bakar pada posisi 1 dan 2 adalah tetap $305^{\circ} \mathrm{K}$ karena fluida melewati grafit, temperatur permukaan bahan bakar pada posisi 3 sampai dengan 10 mengalami kenaikkan secara linier dan temperatur permukaan bahan bakar pada posisi 11 dan 12 turun lagi karena fluida melewati grafit. Hasil temperatur permukaan bahan bakar yang diperoleh masih dalam katagori aman untuk mengoperasikan reaktor dengan pembangkitan daya $6,89 \times 10^{4} \mathrm{watt} / \mathrm{m}^{2}$.

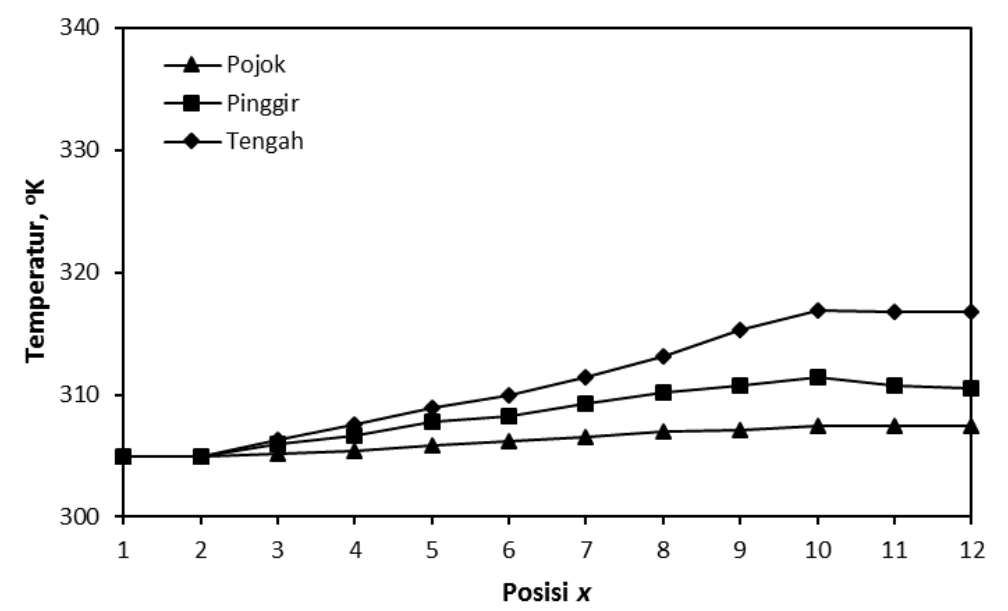

Gambar 8. Distribusi Temperatur Fluida Dengan Kecepatan Awal Fluida 2,0 m/s

\section{DAFTAR PUSTAKA}

[1] Sudjatmi, K.A., Hastuti, E.P., Widodo, S. dan Nazar, R. 2015. “Analisis Konveksi Alam Teras Reaktor Triga Berbahan Bakar Tipe Pelat Menggunakan Coolod-N2”. Jurnal Teknologi Reaktor Nuklir, Vol. 17, No. 2, $67-78$.

[2] Mandala, G.A. 2010. "Simulasi Modifikasi Reaktor Triga 2000 Bandung dengan Bahan Bakar Jenis Pelat”. Seminar Nasional VI SDM Teknologi Nuklir, Yogyakarta, 769 - 776.

[3] Rosyid, M., Hidayat, N. dan Jumari. 2013. "Simulator Reaktor Kartini Sebagai Alat Peraga Operasi Reaktor Penelitian Tipe Triga Mark II”. Seminar Nasional IX SDM Teknologi Nuklir, Yogyakarta, $118-124$.

[4] Antariksawan, A. R., Aliq, Puradwi dan Handoyo, I. 2000. "Evaluasi Disain Sistem Pendingin Reaktor Triga Mark II Bandung Daya 2 MW". Prosiding Presentasi Ilmiah Teknologi Keselamatan Nuklir-V, Serpong, $237-246$.

[5] A. Suwono. 1994. Pendekatan Model Media Berpori Sub-buluh dalam Analisis Termodinamika Berkas Bahan Bakar Reaktor Nuklir. PPTKR-BATAN, Serpong.

[6] M. A. Waskito dkk. 1994. Rencana studi Karakteristik Termohidrolik Sub-buluh dalam Berkas Bahan Bakar Reaktor pada untai Uji Nilo I. PPTKR-BATAN, Serpong.

[7] Sudjatmi, K.A. 2011. "Pengaruh Nilai Bakar terhadap Integritas Kelongsong Elemen Bakar Triga 2000". Jurnal Teknologi Reaktor Nuklir, Vol. 13 No. 3, 186 - 193.

[8] Anonim. (1993). Pre-BFC User's Guide. Version 4.2, Fluent Inc., Lebanon, NH USA.

[9] Anonim. (1993). Fluent Tutorial Guide. Version 4.2, Fluent Inc., Lebanon, NH USA.

[10] Anonim. (1993). Computational Added Design, Fluent User's Guide. Version 4.2, Fluent Inc., Lebanon, NH USA.

[11] Nazar, R., Suwono, A. dan Soelaiman, T. A. F. 1998. "Kaji Teoritik Aspek Termohidrolik Reaktor Riset pada Daya 2 MW”. Jurnal Teknik Mesin, ITB, Vol. XIII-1, 20 - 30. 